\section{OPEN ACCESS}

Approved by:

Frontiers Editorial Office

Frontiers Media SA, Switzerland

*Correspondence:

Tarik Smani

tasmani@us.es

Specialty section:

This article was submitted to

Signaling,

a section of the journal

Frontiers in Cell and Developmental

Biology

Received: 19 March 2021

Accepted: 22 March 2021

Published: 20 April 2021

Citation:

Galeano-Otero I, del-Toro $R$ Khatib A-M, Rosado JA, Ordóñez-Fernández A and Smani T

(2021) Corrigendum: SARAF and Orai1 Contribute to Endothelial Cell

Activation and Angiogenesis.

Front. Cell Dev. Biol. 9:683097.

doi: $10.3389 /$ fcell.2021.683097

\title{
Corrigendum: SARAF and Orai1 Contribute to Endothelial Cell Activation and Angiogenesis
}

\section{Isabel Galeano-Otero 1,2,3, Raquel del-Toro 1,2,3, Abdel-Majid Khatib ${ }^{4}$, Juan Antonio Rosado ${ }^{5}$, Antonio Ordóñez-Fernández ${ }^{2,3,6}$ and Tarik Smani ${ }^{1,2,3 *}$}

${ }^{1}$ Department of Medical Physiology and Biophysics, University of Seville, Seville, Spain, ${ }^{2}$ Group of Cardiovascular Pathophysiology, Institute of Biomedicine of Seville, University Hospital of Virgen del Rocio/University of Seville/CSIC, Seville, Spain, ${ }^{3}$ CIBERCV, Madrid, Spain, ${ }^{4}$ LAMC, INSERM U1029, Pessac, France, ${ }^{5}$ Department of Physiology, University of Extremadura, Caceres, Spain, ${ }^{6}$ Department of Surgery, University of Seville, Seville, Spain

Keywords: Orai1, SARAF, SOCE, HUVEC, angiogenesis

\section{A Corrigendum on}

SARAF and Orail Contribute to Endothelial Cell Activation and Angiogenesis

by Galeano-Otero, I., Del Toro, R., Khatib, A.-M., Rosado, J. A., Ordóñez-Fernández, A., and Smani, T. (2021). Front. Cell Dev. Biol. 9:639952. doi: 10.3389/fcell.2021.639952

There is an error in the Funding statement. The correct funding statement is: "This research was funded by Agencia Estatal de Investigación [PID2019-104084GBC22/AEI/10.13039/501100011033]".

The authors apologize for this error and state that this does not change the scientific conclusions of the article in any way. The original article has been updated.

Copyright (๑) 2021 Galeano-Otero, del-Toro, Khatib, Rosado, Ordóñez-Fernández and Smani. This is an open-access article distributed under the terms of the Creative Commons Attribution License (CC BY). The use, distribution or reproduction in other forums is permitted, provided the original author(s) and the copyright owner(s) are credited and that the original publication in this journal is cited, in accordance with accepted academic practice. No use, distribution or reproduction is permitted which does not comply with these terms. 